\title{
Effects of Organic Weed Control Methods on Weed Density, Phenotypic Traits and Yield Attribute of Cucumber (Cucumis Sativus)
}

\author{
Osundare O.T*1 ${ }^{1} \quad$ Badmus A.A ${ }^{1} \quad$ Olatubosun O.A ${ }^{2}$ \\ 1.Department of Crop Science and Horticulture, Federal University Oye Ekiti, Ekiti State, Nigeria \\ 2.Department of Agricultural Education \\ Ekiti State College of Education, Ikere, Ekiti State, Nigeria
}

\begin{abstract}
Organic weed control methods has a long time record in conserving soil moisture, improving soil structure and increasing soil organic matter. This testimonial should not be left out to manifest on vegetable crops that serve greater part as supplement for balanced meals. Field experiment was conducted in two years (2016 and 2017) to investigate the effects of different organic weed control methods on weed density, phenotypic traits and yield of Cucumber. The experiment was laid out in Randomized Complete Block Design (RCBD) with three replications. The experimental site was marked into (4) blocks while each block was also marked into (3) plots, giving a total number of (12) plots. Plots were $4 \mathrm{~m} \times 4 \mathrm{~m}$. Two seeds were planted per hole with inter and intra row spacing of $1 \mathrm{~m} \times 1 \mathrm{~m}$.The results showed that mulched plots (Sawdust and wood shaving) and hoe weeding had higher and significant growth and harvested number of fruits per plant (yield), compared to the control (Weedy and nonmulched plots), this indicated that mulching and hoe weeding as methods of organic weed control have positive effects on reducing weed emergence, increase growth and yield of cucumber. It was concluded that higher yield is not only synonymous to use of synthetic chemicals (pesticides and herbicides) but as well to cost effective and safe organic management practices in breeding programmes.
\end{abstract}

Keywords: Organic, weed control, weed density, phenotypic traits and yield attributes.

DOI: $10.7176 / \mathrm{JBAH} / 9-10-12$

Publication date:May $31^{\text {st }} 2019$

\section{INTRODUCTION}

Cucumber (Cucumis sativus) is a widely grown plant in the gourd family, Cucurbitaceae. It is a creeping vine that bears cucumiform fruits that are used as vegetables. There are three main varieties of Cucumber, which are slicing, pickling and seedless (Doijode, 2001). Within these varieties, several cultivars have been breed to suit consumer's trait of preference (Renner et al., 2007). In the North America, the term 'wild cucumber' refers to plants in the genera Echinocystis and Marah, but these are not close related. Cucumber is originally from South Asia, but now grows on most continents. Many different types of Cucumber are now traded on the global market (FAOSTAT, 2018).

Cucumber contains carbohydrates, fat, protein, vitamins, minerals encapsulated in about $95 \%$ water present in its fruit. It is a creeping vine that roots in the ground and grows up trellises or other supporting frames, wrapping around supports with thin, spiraling tendrils. The plant may also root in a soilless medium and will sprawl along the ground if it does not have supports. The vines have large leaves that form a canopy over the fruits. The fruit of cultivars of cucumber is roughly cylindrical, but elongated with tapered ends, and may be as large as $60 \mathrm{~cm}$ long and $10 \mathrm{~cm}$ in diameter. A few cultivars of cucumber are parthenocarpic, the blossoms creating seedless fruit without pollination (Fuentes and Schupp, 1998). Pollination of these cultivars degrades in quality.

Weeds have been a great problem to agricultural production and attempt to combat weeds interaction with desired crop have been efforts towards improving production and ensuring sustainable agriculture. Broad leaved, sedges and grasses have been identified as serious problem to the yield and full expression of traits Cucumis sativum (Hector et al., 2016). Weeds reduce the yield of vegetables by competing with crops for water, nutrients and light (Adams et al., 1992). Lichtenstein et al., 1962, Bartha et al., 1967 and Gigliotti and Allievi, 2001 reiterated that most soils under vegetable cultivation are contaminated with pesticides. Gafar et al., 2010 also confirmed that pesticide residues have been found in vegetables, cereals and fruits, as crop pollution and as reduced both yield and quality. Many of these chemicals were abnormally used to control weeds and pests on crops, making it unsafe for human. Weeds are managed in three different ways; avoidance, control and eradication. The objective of this research is to determine organic weed control methods for cucumber cultivation and also to determine cost effective and safe weed management practice for the optimum growth and yield of Cucumber. 


\section{MATERIALS AND METHODS}

The study was carried out at the Teaching and Research Farm, Federal University Oye Ekiti. The place is characterized a tropical climate with $1500 \mathrm{~mm}$ average rainfall per annum, $27^{\circ} \mathrm{c}$ average temperature with high relative humidity in the raining season that last for about eight months in a year. The land has long been subjected to cultivation of arable crops such as maize, cassava and cowpea. Total manual clearing was done followed by minimum soil tillage of the plots.

A variety of hybrid seeds of Cucumber were obtained from Agro allied shop in Nigeria for the purpose of this experiment. Treatments used were (i) $5 \mathrm{~kg}$ of sawdust (wood particles) mulch on $4 \mathrm{~m} \mathrm{x} 4 \mathrm{~m}$ area of land, (ii) $5 \mathrm{~kg}$ of wood shavings mulch on $4 \mathrm{~m} \times 4 \mathrm{~m}$ area of land, (iii) hoe weeding and (iv) no mulch, no weeding (check) were adopted weed management practices for this study.

Treatments were replicated thrice on manually cleared and tilled land, and then laid out in a Randomized Complete Block Design (RCBD). The experimental site was marked into (4) blocks while each block was also marked into (3) plots, giving a total number of (12) plots. Plots were $4 \mathrm{~m} \mathrm{x} 4 \mathrm{~m}$ with plant population of 25 plants per plot and total experimental area was $21 \mathrm{~m} \times 15 \mathrm{~m}$. Two seeds were planted per hole with inter and intra row spacing of $1 \mathrm{~m} \times 1 \mathrm{~m}$.

\section{Data collection}

Data collection started one week after planting (1WAP) and this continued to the end of the growing period. The data collected were centered on the following parameters; Plant height $(\mathrm{PHcm})$, vine length (VLcm), leaf length $(\mathrm{LLcm})$, leaf width $(\mathrm{LWcm})$, number of leaves $(\mathrm{NL})$, number of flowers per plant (NFL/P), harvested number of fruits per plant $(\mathrm{HFR} / \mathrm{P})$, average fruit girth $(\mathrm{AFG})$, average fruit weight per plot $(\mathrm{AFW} / \mathrm{P})$, average fruit weight per plant $(\mathrm{AVFW} / \mathrm{PL})$, average fruit length $(\mathrm{AFL})$, total average fruit weight per plot (TAVFW/P) and yield $(\mathrm{kg} / \mathrm{ha})$. The number added to the acronyms of the traits as indicated above in the study is the week $(\mathrm{s})$ of observation.

Data collected on weeds include weed type, weed emergence, fresh weight and dry weight of the categories of weeds observed.

\section{Data analysis}

Data collected were subjected to analysis of variance (ANOVA) using general linear model (GLM) procedure for Randomized Complete Block Design in SAS (9.3). Correlation between traits were determined using the Proc corr procedures of SAS (SAS Institute, Cary NC).

\section{RESULTS AND DISCUSSION}

Table 1 showed there was no significant difference in the vine length (VL), leaf length (LL), leaf width (LW) and number of leaves (NL) observed at four weeks interval after planting, this might be due to the fact that the treatments have not really taken effect on the physiology of the plants, since they were applied 2 weeks after planting to ensure favourable germination conditions on the planted seeds. This could also be due to the conserved amount of water content on soil particles before the amendment which could still sustain optimal growth of the plants initially, and rate of physiological growth could not be differentiated, such that translocation of assimilate is not noticeable by the plants (Goitom et al., 2017). There was significance difference in the (LL) at 6 weeks after planting, hoe weeding (HW) had the highest (16.09a) and the lowest for sawdust (13.09c), this may be due to the initial response of the plant to the mulching materials used in this study, this growth stage of the crop is known as vegetative. The depressed weed emergence due to mulch treatments had no positive role in cucumber plants at the early stage (vegetative) as compared to no mulch plots (Wdy) which had shown no retarded symptoms on the growth of cucumber, since the crop itself serves as cover crop at the stage. The extended retention and availability of moisture also led to higher uptake of nutrient for proper growth and development.

(LW and NL) at 6weeks were not significantly different. Number of flowers per plant at 4 weeks (NFL/P4) and number of flowers per plant at 6 weeks (NFL/P6) were not significantly different for all the treatments.

In table 2 and 3, hoe weeding (HW) had the highest and significant harvested number of fruits per plant (HFR/P) at 6 and 7 week after planting at 6 weeks (2.25) and wood shaving (WS) having the highest at 7 and 8 weeks (19.00a and 13.00a) respectively.

Average fruit girth (AFG) at 6weeks were significantly different with $(\mathrm{HW})$ having the highest fruit girth mean (15.98a), but (HW) was not significantly different among other treatments in week 7 and 8 , even when there were increase in the fruit girth.

Average fruit weight $(\mathrm{g})$ per plot $(\mathrm{AFW} / \mathrm{P})$ at 6 weeks was significantly different and highest mean value was recorded for (HW) (483.31g) and lowest for sawdust (SD) $(0.00 \mathrm{~g})$, where no fruit were harvested in all the plots at 6 weeks. At week 7 and 8 after planting, wood shaving (WS) had the highest mean value $(5800.00 \mathrm{~g}$ and $5625.00 \mathrm{~g}$ ) among the treatments respectively. It was observed that all treatments with mulching material 
significantly increased in average fruit weight $(\mathrm{kg})$ of cucumber than control (weedy check) at 7 and 8 weeks.

Average fruit weight per plant (AFW/PL) at 6week was highest for hoe weeding (HW) (213.37g) and lowest mean obtained for sawdust.

Among all mulching treatments, maximum average fruit weight was recorded in wood shaving (WS). It appears that wood shaving (WS) used as weed control check might have induced favourable conditions conducive to attainment of fruits setting with higher weight. The above results were in agreement with those of Ansary and Roy (2005), Arancibia and Motsenbocker (2008) in watermelon, Sharma and Agrawal (2004), Aruna et al. (2007) in tomato and Angrej-Ali and Gaur (2007) in strawberry. It was found in this study, that all the treatments with mulching material significantly increased the fruit yield of cucumber. The above results were in consonance with those of Johnson et al. (2000), Deanban et al. (2004), Ansary and Roy (2005), Cenobio et al. (2007) and Arancibia and Motsenbocker (2008) in watermelon, Ibarra-Jimenez et al. (2008), Hallidri (2001) in cucumber, Ibarra et al. (2001) in muskmelon.

Average fruit weight per plant (AVFW/PL) at 7 and 8 weeks were not significantly different but wood shavings (WS) had the highest mean (580.00a) and lowest mean was recorded for weedy (Wdy) (437.50ab) at 8 weeks after planting, this mulch consistently increased higher fruit set than no mulch and weedy plots. This might have been influenced by favourable soil temperature, moisture conditions and depressed weed emergence control as influenced by wood shavings. The present finding was in accordance with Johnson et al. (2000), Ansary and Roy (2005) in watermelon and Hanna (2000) in cucumber.

Average fruit length (AFL) at 6 weeks was highest for (HW) (19.08a), but at 8weeks there were no significant differences among the treatments.

Average fruit girth (AFG) at 7 and 8weeks were significantly different with (WS) having the highest mean values (19.24a and 20.36a) respectively.

Total average fruit weight per plot (TAVFW/P) were significantly different, (WS) and (SD) had the highest mean value (429.97a and 400.00a) respectively, while weedy check (Wdy) (control) had the lowest mean values (340.16ab). Yield/ha was highest for (WS and SD) with mean values of 4.29t/ha and 4.00t/ha respectively, while the (Wdy) had the lowest mean yield/ha value of 3.20t/ha.

Table 4 and 5 showed the emergence of weeds with the category of weeds emerged to the treatments, in this study weedy (Wdy) had the highest emergence of grass weeds $(20 \%)$ while (HW) had the lowest emergence $(9 \%)$, weeds emergence of all the categories considered were highest for the (Wdy) (control) treatment in all the weeks considered in the study. This might have been influenced by the exposure of weed seeds dormant in the soil to favourable conditions for germination. Fresh and dry weights for all the categories of weeds observed in this study were highest for weedy (Wdy) control treatment and were significantly different among other treatments adopted in this study. Broadleaf weeds (BRDLW) emergence were highest for the categories of weeds emergence observed (61.75\%), followed by grasses (GRW) (20\%), all on the (Wdy) plots and were significantly different from other weed check treatments, since (SD) and (WS) treatments were weed free. Total weight of dry weeds (TWDW) obtained at 12 weeks was higher than total weight of dry weeds obtained at 4weeks.

Table 6 showed the significance of correlation coefficients on the effect of weeds emergence on the yield, nine of the weeds attribute considered in this study showed negative but not significant correlation with yield. This implies that increase in the emergence of any category of weeds for cucumber reduces the yield and increasing yield for cucumber plant is associated with decreasing weeds. Sedges weed (SDGW) showed the highest negative correlation with yield in all the weeks observed for this study $(-0.51)$, while broad leaf weeds (BRDLW) (-0.39) and grass weeds (GRW) (-0.24) also had negative correlation with yield respectively. Fresh weight of broad leaf at 12 weeks (FWBRL12) was highly correlated and significant with broad leaf weeds (BRDL) (0.94) emergence. There was high and significant correlation of (BRDL) emergence with dry weight of broad leaf weeds (DWBRDL) and total weight of dried weed (TWDW) (0.98) respectively. This implies that the categories of weeds observed in this study had favourable association in their growth pattern, hence no allelopatic effect on one another. Significant correlation was also observed for dry weight of sedges (DWSDG) and (BRDL) (0.89) emergence. There was high correlation between Fresh weight of broad leaf (FWBRDL) and (BRDL) emergence. Fresh weight of broad leaf (FWBRDL) had correlation with grass weeds emergence (GRW) (0.82), fresh weight of sedges (FWSG) was correlated with (SGDW) (0.92) emergence, fresh weight of grass weeds emergence (FWGR) had high correlation with (SDGW) (0.84). Fresh weight of broad leaf (FWBRL) was also correlated with dry weight of broad leaf (DWBR) (0.94), while fresh weight of grass emergence (FWGR) was highly correlated with dry weight of grass weeds $(0.99)$ respectively.

Table 7 showed the correlation of the phenotypic traits and their contribution to the yield of cucumber, two of the traits were highly correlated and significant to the yield of cucumber at both levels of significance. Harvested fruit per plot (HFR/P) and total average fruit weight per plot (TAVFW/P) were highly correlated with yield (tons/ha) at 0.95 and 0.99 respectively, this implies that increase in the number of harvested fruit per area of land and increased fruit weight of cucumber results to increasing yield. Relevant research findings were also 
reiterated by Hanna (2000), Ibarra et al. (2008) in cucumber. Other phenotypic traits considered in this study such as leaf length (LL), leaf width (LW), vine length $(\mathrm{VL})$, number of leaves $(\mathrm{NL})$ and number of flowers per plant (NFL/P) were positively correlated but not significant with yield (tons/ha).

\section{CONCLUSION}

Based on the weed control methods adopted, we conclude that Cucumis responds to weed management techniques in the expression of its phenotypic traits and yield. Cucumis sativus could be best grown with plant mulch materials used and hoe weeding as effective weed management practices towards yield increase. It was also concluded that higher yield is not only synonymous to use of synthetic chemicals (pesticides and herbicides) but as well to cost effective and safe organic management practices in breeding programmes.

\section{REFERENCES}

Adams P., Graves C.J. and Winsor G.W. 1992. Some responses of Cucumber grown in beds of peat to N, K and Mg. J. Hort. Sci. 67: 877-884

Angrej A. and Gaur, G. S. 2007. Effect of mulching on growth, fruit yield and quality of strawberry (Fragaria x ananassa Duch.). Asian J. Hort., 2(1): 149-151.

Ansary, S.H. and Roy, D. C. 2005. Effect of irrigation and mulching on growth, yield and quality of watermelon (Citrullus lanatus Thunb.). Environment and Ecology, 23(Spl-1): 141-143.

Arancibia, R. A. and Motsenbocker, C. E. 2008. Differential watermelon fruit size distribution in response to plastic mulch and spunbonded polyester rowcover. Hort.Tech., 18(1): 45-52.

Aruna, P., Sudagar, I.P., Manivannan, M. I., Rajangam, J and Natarajan, S. 2007. Effect of fertigation and mulching for yield and quality in tomato cv. PKM-1. Asian J. Hort., 2(2): 50-54.

Bartha, R., R.P. Lanzilotta and D. Pramer .1967. Stability and effects of some pesticides in soil. Appl. Environ. Microbiol. asm.asm.org content/15/167 (2013)

Cenobio Pedro, G., Inzunza Ibarra, M. A., Mendoza Moreno, S. F.; Sanchez Cohen, I.; and Roman Lopez, A. 2007. Response of watermelon to colored plastic mulches under drip irrigation. Terra., 24(4): 515-520.

Dean Ban.; Zanic K., Dumicic, G., Culjak, T. G. and Ban S. G. 2004. The type of polythene mulch impacts vegetative growth, yield and aphid populations in watermelon production. J. Food, Agri. and Envi., 7 (3-4): 543-550.

Doijode, S. D. 2001. Seed storage of horticultural crops. Haworth Press. ISBN 1-56022-901-2 p. 281

FAOSTAT. Retrieved 2018-08-25. Countries - Select All; Regions - World + (Total); Elements - Production Quantity; Items - Cucumbers and gherkins; Years - 2016

Fuentes $M$ and Schupp EW .1998. "Empty seeds reduce seed predation by birds in Juniperus osteosperma". Evolutionary Ecology. 12 (7): 823-7. doi:10.1023/A:1006594532392.

Gafar M.O., Y. M. Dagash, M. Mustafa and O. M. Alzen .2010. The Residual effect of Malathion (Organophosphate) and Sevin (Carbamate) application on sugar beet (Chenpodiaceae) Growth, Journal of Science and Technology 11 (2) ISSN 1605 - 427X Sudan University of Science and Technology

Gigliotti, C., and L, Allievi. 2001. Differential effects of the herbicides Bensulphuron and Cinosulphuron on soil microorganisms. Journal of Environmental Science and Health, Part B: Pesticides, Food Contaminants, and Agricultural Wastes 36(6), 775 - 782.

Goitom T., Alemtsaha T. and Berhanu A. 2017. Effect of organic mulching on soil moisture, yield and yield contributing components of Sesame. International Journal of Agronomy. doi.org. 10.1155/2017/4767509

Hallidri, M. 2001. Comparison of the different mulching materials on the growth, yield and quality of cucumber (Cucumis sativus L.). Acta Hort., 559: 49-54.

Hanna, H. Y. 2000. Black polyethylene mulch does not reduce yield of cucumbers double-cropped with tomatoes under heat stress. Hort. Sci., 35(2): 190-191

Hector Valenzuela, Randall T. Hamasaki and Steve Fukuda .2016. Field cucumber production guidelines for Hawaii. Univ. of Hawaii Coop. Extension service.

Ibarra, L., Flores, J. and Diaz Perez J. C. (2001). Growth and response to plastic mulch and row covers. Scientia Horticulturae, 87(1/2): 139-145.

Ibarra Jimenez, L. Zermeno Gonzalez, A., Munguia Lopez, J., Quezada Martin, M. A. R. and Rosa Ibarra, M. de La. 2008. Photosynthesis, soil temperature and yield of cucumber as affected by colored plastic mulch. Acta Agriculturae Scandinavica Section B, Plant Soil Science, 58(4): 372-378.

Johnson J. M., Hough Goldstein J. A. and Vangessel M. J. 2000. Effects of Straw Mulch on Pest Insects, Predators, and Weeds in Watermelons and Potatoes. Environmental Entomology, 33: 1632-1643.

Lichtenstein, E.P., W.F. Millingten and G.T.Cowley .1962. Effects of various insecticides on growth and respiration of plants. J. Agric. Food Chem. 10 (3), 251-256. Pubs. Acs.org. (2013)

Renner, SS; Schaefer, H; Kocyan, A .2007. Phylogenetics of Cucumis (Cucurbitaceae): Cucumber (C. sativus) belongs in an Asian/Australian clade far from melon (C. melo). BMC Evolutionary Biology. 7: 58. 
doi:10.1186/1471-2148-7-58. PMC 3225884. PMID 17425784.

SAS Institute. 1999. American multinational developer of analytics software, Cary, North Carolina State University, USA.

Sharma, H. G. and Agrawal, Narendra .2004. Effect of different colour mulches on the growth and yield of tomato under drip irrigation. Plant Archives., 4(1): 93-99.

\section{LIST OF TABLES}

Table1: Mean performance of cucumber evaluated for organic weed management practices (2016 and 2017 years)

\begin{tabular}{|c|c|c|c|c|c|c|c|c|c|c|}
\hline \multirow[t]{2}{*}{ Treatments } & \multicolumn{10}{|c|}{ Weeks of observation (cm) (traits) } \\
\hline & VL4wks & VL6WKS & LL4WKS & LL6WKS & LW4WKS & LW6WKS & NL4WKS & NL6WKS & NFL/P4 & NFL/P6 \\
\hline ws & $14.72 \mathrm{a}$ & $15.73 \mathrm{a}$ & $14.41 \mathrm{a}$ & $15.41 \mathrm{ab}$ & $18.69 \mathrm{a}$ & $19.34 \mathrm{a}$ & $17.25 \mathrm{a}$ & $27.50 \mathrm{a}$ & $6.56 \mathrm{a}$ & $20.06 a$ \\
\hline HW & $17.18 \mathrm{a}$ & $18.00 \mathrm{a}$ & $14.99 \mathrm{a}$ & $16.09 \mathrm{a}$ & $18.79 \mathrm{a}$ & $19.31 \mathrm{a}$ & $18.75 a$ & $27.25 a$ & $7.23 \mathrm{a}$ & $21.56 \mathrm{a}$ \\
\hline Wdy & $16.95 \mathrm{a}$ & $18.03 \mathrm{a}$ & $12.81 \mathrm{a}$ & $13.96 \mathrm{bc}$ & $17.13 \mathrm{a}$ & $17.95 \mathrm{a}$ & $15.87 \mathrm{a}$ & $28.87 a$ & $4.81 \mathrm{a}$ & $18.37 \mathrm{a}$ \\
\hline SD & $15.00 \mathrm{a}$ & $15.40 \mathrm{a}$ & $12.59 \mathrm{a}$ & $13.09 \mathrm{c}$ & $16.81 \mathrm{a}$ & $17.02 \mathrm{a}$ & $15.56 \mathrm{a}$ & $24.37 a$ & $5.08 \mathrm{a}$ & $19.00 \mathrm{a}$ \\
\hline AMs & 6.59 & 8.06 & 5.61 & 7.42 & 4.24 & 5.08 & 8.50 & 14.29 & 5.40 & 7.78 \\
\hline MsE & 2.50 & 1.67 & 2.44 & 0.95 & 3.30 & 2.27 & 13.52 & 46.95 & 8.38 & 25.84 \\
\hline
\end{tabular}

Mean in a column with the same letter(s) are not significantly different by Tukey test $(\mathrm{P}=0.05)$

Table 2: Mean performance of cucumber evaluated for organic weed management (2016 and 2017 years)

\begin{tabular}{|c|c|c|c|c|c|c|c|c|c|c|}
\hline \multirow[t]{2}{*}{ Treatments } & \multicolumn{10}{|c|}{ Weeks of observation (cm and g) (traits) } \\
\hline & HFR/P6 & HFR/P7 & $\mathrm{HFR} / \mathrm{P} 8$ & AFG6 & AFW/P6g & AFW/PL6 & AFW/PL8 & AFL@6 & AFL@7 & AFG@7 \\
\hline WS & $1.50 \mathrm{ab}$ & $19.00 \mathrm{a}$ & $13.00 \mathrm{a}$ & $8.15 \mathrm{ab}$ & $322.20 \mathrm{ab}$ & $107.41 \mathrm{ab}$ & $580.00 \mathrm{a}$ & $9.80 \mathrm{ab}$ & $22.22 \mathrm{a}$ & $19.24 \mathrm{a}$ \\
\hline HW & $2.25 \mathrm{a}$ & $13.25 \mathrm{ab}$ & $10.50 \mathrm{a}$ & $15.98 \mathrm{a}$ & $483.31 \mathrm{a}$ & $213.37 \mathrm{a}$ & $512.50 \mathrm{a}$ & $19.08 \mathrm{a}$ & $22.61 \mathrm{a}$ & $18.70 \mathrm{a}$ \\
\hline Wdy & $0.25 b$ & $4.00 \mathrm{bc}$ & $7.50 \mathrm{a}$ & $3.87 \mathrm{ab}$ & $52.98 b$ & $52.98 \mathrm{ab}$ & $437.50 \mathrm{ab}$ & $5.00 \mathrm{ab}$ & $15.53 \mathrm{ab}$ & $13.18 \mathrm{ab}$ \\
\hline $\mathrm{SD}$ & $0.00 \mathrm{~b}$ & $2.75 \mathrm{c}$ & $5.00 \mathrm{~b}$ & $0.00 \mathrm{~b}$ & $0.00 \mathrm{~b}$ & $0.00 \mathrm{~b}$ & $530.00 \mathrm{a}$ & $0.00 \mathrm{~b}$ & $19.87 \mathrm{a}$ & $17.17 \mathrm{a}$ \\
\hline AMs & 4.5 & 239.83 & 48.67 & 187.7 & 207947 & 3523 & 33262 & 264.38 & 42.36 & 30 \\
\hline MsE & 0.87 & 24.46 & 28.17 & 37.24 & 41892 & 14698 & 6701 & 57.18 & 28.75 & 19.78 \\
\hline
\end{tabular}

Mean in a column with the same letter(s) are not significantly different by Tukey test $(\mathrm{P}=0.05)$

Table 3:

\begin{tabular}{lcclllll}
\hline Treatments & \multicolumn{6}{l}{ Weeks of observation (cm and g) (traits) } \\
\cline { 2 - 8 } & AFG@, 8 & AFL@ $@ 8$ & AFW/PL7 & AFWP7g & AFWP8 & TAVFW/P & Y/Ha(tons) \\
\hline WS & $20.36 \mathrm{a}$ & $22.32 \mathrm{a}$ & $357.50 \mathrm{a}$ & $5800.00 \mathrm{a}$ & $5625.00 \mathrm{a}$ & $429.97 \mathrm{a}$ & $4.29 \mathrm{a}$ \\
HW & $19.13 \mathrm{a}$ & $22.46 \mathrm{a}$ & $387.50 \mathrm{a}$ & $4125.00 \mathrm{ab}$ & $3900.00 \mathrm{a}$ & $371.12 \mathrm{a}$ & $3.70 \mathrm{a}$ \\
Wdy & $19.05 \mathrm{a}$ & $21.94 \mathrm{a}$ & $235.00 \mathrm{a}$ & $1300.00 \mathrm{~b}$ & $2525.00 \mathrm{a}$ & $340.16 \mathrm{ab}$ & $3.20 \mathrm{ab}$ \\
SD & $18.47 \mathrm{a}$ & $20.90 \mathrm{a}$ & $270.00 \mathrm{a}$ & $837.50 \mathrm{~b}$ & $1925.00 \mathrm{a}$ & $400.00 \mathrm{a}$ & $4.00 \mathrm{a}$ \\
AMs & 2.52 & 1.98 & 20617 & 22228073 & 10123958 & 2806 & 0.28 \\
MsE & 1.29 & 2.28 & 10721 & 2552865 & 4985208 & 5378 & 0.53
\end{tabular}

Mean in a column with the same letter(s) are not significantly different by Tukey test $(\mathrm{P}=0.05)$

Table 4: Mean weed emergence and weight of weed categories on cucumber evaluated for organic weed management practices in two years

\begin{tabular}{|c|c|c|c|c|c|c|c|c|c|c|c|}
\hline \multirow[t]{3}{*}{ Treatments } & \multicolumn{11}{|c|}{ Weeks of observation ( 4 \& 12 weeks after planting) } \\
\hline & BRDLW & $\underline{\text { GRW }}$ & SDGW & FWBRL & FWGR & FWSDG & DWBRL & DWGR & DWSDG & TTWDW & BRDL1 \\
\hline & 4 & $\underline{4}$ & 4 & 4 & 4 & 4 & 4 & 4 & 4 & 4 & 2 \\
\hline WS & $9.50 \mathrm{~b}$ & $2.50 \mathrm{a}$ & $0.00 \mathrm{a}$ & $17.58 \mathrm{~b}$ & $4.54 \mathrm{a}$ & $0.00 \mathrm{~b}$ & $7.08 \mathrm{a}$ & $1.60 \mathrm{a}$ & $0.00 \mathrm{a}$ & $8.68 \mathrm{a}$ & $31.75 b$ \\
\hline HW & $16.00 \mathrm{a}$ & $1.25 \mathrm{a}$ & $1.75 \mathrm{a}$ & $24.92 \mathrm{a}$ & $4.72 \mathrm{a}$ & $0.81 \mathrm{ab}$ & $7.25 \mathrm{a}$ & $1.42 \mathrm{a}$ & $0.23 \mathrm{a}$ & 8.91a & $32.00 \mathrm{~b}$ \\
\hline Wdy & $18.25 \mathrm{a}$ & $2.50 \mathrm{a}$ & $2.50 \mathrm{a}$ & $25.55 \mathrm{a}$ & $0.92 \mathrm{a}$ & $2.88 \mathrm{a}$ & $7.60 \mathrm{a}$ & $0.53 \mathrm{a}$ & $0.34 \mathrm{a}$ & $8.48 \mathrm{a}$ & $61.75 \mathrm{a}$ \\
\hline SD & $8.75 b$ & $0.00 \mathrm{a}$ & $0.00 \mathrm{a}$ & $16.82 b$ & $0.00 \mathrm{a}$ & $0.00 \mathrm{~b}$ & $4.95 b$ & $0.00 \mathrm{a}$ & $0.00 \mathrm{a}$ & $4.95 \mathrm{~b}$ & $29.50 \mathrm{~b}$ \\
\hline AMs & 89.08 & 5.72 & 6.39 & 86.67 & 23.78 & 7.4 & 5.77 & 2.28 & 0.11 & 14.12 & 945.50 \\
\hline MsE & 3.20 & 4.56 & 2.47 & 1.69 & 14.82 & 1.34 & 0.61 & 1.55 & 0.07 & 1.35 & 6.70 \\
\hline
\end{tabular}

Mean in a column with the same letter(s) are not significantly different by Tukey test $(\mathrm{P}=0.05)$ 
Table 5: Mean weight $(\mathrm{g})$ of weed categories on cucumber evaluated for organic weed management practices in two years

\begin{tabular}{lllllllllll}
\hline \multirow{2}{*}{ Treatments } & \multicolumn{1}{l}{ Weeks of observation } & $(12$ weeks after planting) \\
\cline { 2 - 10 } & GRW12 & SDGW12 & FWBRL12 & FWGR12 & FWSG12 & DWBR12 & DWGR12 & DWSD12 & TWDW12 \\
\hline WS & $12.00 \mathrm{~b}$ & $5.50 \mathrm{~b}$ & $278.55 \mathrm{~b}$ & $22.85 \mathrm{~b}$ & $\mathbf{8 . 7 4 a b}$ & $126.45 \mathrm{c}$ & $6.36 \mathrm{~b}$ & $2.48 \mathrm{~b}$ & $135.32 \mathrm{c}$ \\
HW & $9.00 \mathrm{~b}$ & $6.25 \mathrm{~b}$ & $285.35 \mathrm{~b}$ & $22.73 \mathrm{~b}$ & $9.06 \mathrm{ab}$ & $132.65 \mathrm{~b}$ & $6.08 \mathrm{~b}$ & $2.42 \mathrm{~b}$ & $141.17 \mathrm{~b}$ \\
Wdy & $20.00 \mathrm{a}$ & $9.00 \mathrm{a}$ & $417.45 \mathrm{a}$ & $30.27 \mathrm{a}$ & $11.42 \mathrm{a}$ & $178.95 \mathrm{a}$ & $\mathbf{8 . 1 3 a}$ & $3.42 \mathrm{a}$ & $190.50 \mathrm{a}$ \\
SD & $12.75 \mathrm{~b}$ & $3.00 \mathrm{c}$ & $272.72 \mathrm{~b}$ & $9.85 \mathrm{c}$ & $6.62 \mathrm{~b}$ & $124.3 \mathrm{c}$ & $2.61 \mathrm{c}$ & $2.31 \mathrm{~b}$ & $129.22 \mathrm{~d}$ \\
AMs & 81.39 & 24.39 & 19309.5 & 287.82 & 15.47 & 2666.45 & 21.29 & 1.06 & 3148.70 \\
MsE & 4.64 & 1.31 & 553.1 & 0.99 & 2.06 & 5.29 & 0.05 & 0.04 & 4.68 \\
\hline
\end{tabular}

Mean in a column with the same letter(s) are not significantly different by Tukey test $(\mathrm{P}=0.05)$

Table 6: Correlation coefficients showing the effects of weed emergence on the yield of cucumber (2016 and 2017)

\begin{tabular}{|c|c|c|c|c|c|c|c|c|c|c|c|c|c|}
\hline \multirow[t]{2}{*}{ Weeds } & & \multicolumn{12}{|c|}{ Weed emergence and the categories } \\
\hline & \multicolumn{2}{|r|}{ AFWP8 } & BRDL & GRW & SDGW & FWBRL & FWGR & FWSG & DWBR & DWGR & DWSD & TWDW & $\mathbf{Y} / \mathbf{H a}$ (tons) \\
\hline AFWP8 & \multicolumn{2}{|r|}{1} & & & & & & & & & & & \\
\hline \multicolumn{14}{|l|}{ TAVFW/P } \\
\hline BRDL & \multicolumn{2}{|r|}{-0.16} & 1 & & & & & & & & & & \\
\hline GRW & \multicolumn{2}{|r|}{-0.13} & 0.82 & 1 & & & & & & & & & \\
\hline SDGW & \multicolumn{2}{|r|}{0.03} & 0.77 & 0.47 & 1 & & & & & & & & \\
\hline FWBRL & \multicolumn{2}{|r|}{0.26} & $0.94^{*}$ & 0.82 & 0.73 & 1 & & & & & & & \\
\hline FWGR & \multicolumn{2}{|r|}{0.19} & 0.72 & 0.46 & 0.84 & 0.69 & 1 & & & & & & \\
\hline FWSG & \multicolumn{2}{|r|}{0.11} & 0.68 & 0.50 & $0.92^{*}$ & 0.66 & 0.76 & 1 & & & & & \\
\hline DWBR & \multicolumn{2}{|r|}{-0.21} & $0.98^{* *}$ & 0.79 & 0.80 & $0.94^{*}$ & 0.74 & 0.70 & 1 & & & & \\
\hline DWGR & \multicolumn{2}{|r|}{0.19} & 0.70 & 0.45 & 0.86 & 0.67 & $0.99^{* \star}$ & 0.77 & 0.72 & 1 & & & \\
\hline DWSD & \multicolumn{2}{|r|}{-0.12} & $0.89^{*}$ & 0.77 & 0.69 & 0.83 & 0.71 & 0.65 & $0.89^{*}$ & 0.70 & 1 & & \\
\hline TWDW & \multicolumn{2}{|r|}{-0.18} & $0.98^{* *}$ & 0.78 & 0.82 & $0.94^{*}$ & 0.78 & 0.72 & $0.99^{* *}$ & 0.76 & $0.90^{*}$ & 1 & \\
\hline $\mathrm{Y} / \mathrm{Ha}$ (tons) & \multicolumn{2}{|r|}{0.40} & -0.39 & -0.24 & -0.51 & -0.41 & -0.20 & -0.57 & -0.40 & -0.2 & -0.28 & 0.42 & 1 \\
\hline \multicolumn{14}{|c|}{ *significant @ $\mathrm{P} \leq 0.05, * *$ significant $@ \mathrm{P} \leq 0.01$} \\
\hline \multicolumn{14}{|c|}{ Table 7: Correlation coefficients showing the phenotypic traits of cucumber in relation to yield (2016 and 2017 ) } \\
\hline \multicolumn{14}{|l|}{ Traits } \\
\hline & VL & LL & LW & NL & NFL/P & HFR/P & & AFG & AFL & AFWP & TA & FW/P & Y/Ha(tons) \\
\hline VL & 1 & & & & & & & & & & & & \\
\hline$\underline{\mathbf{L} L}$ & 0.42 & 1 & & & & & & & & & & & \\
\hline LW & 0.41 & 0.81 & 1 & & & & & & & & & & \\
\hline NL & 0.48 & 0.37 & 0.58 & 1 & & & & & & & & & \\
\hline NFL/P & 0.35 & 0.45 & 0.60 & 0.84 & 1 & & & & & & & & \\
\hline HFR/P & 0.32 & 0.63 & 0.61 & 0.34 & 0.39 & 1 & & & & & & & \\
\hline$\underline{\mathbf{A F G}}$ & 0.22 & 0.58 & 0.37 & 0.41 & 0.35 & 0.65 & & 1 & & & & & \\
\hline AFL & 0.41 & 0.52 & 0.38 & 0.33 & 0.21 & 0.49 & & 0.69 & 1 & & & & \\
\hline AFWP & 0.24 & 0.66 & 0.61 & 0.34 & 0.45 & $0.95^{* *}$ & & 0.76 & 0.5 & 1 & & & \\
\hline TAVFW/P & 0.01 & 0.14 & 0.15 & 0.02 & 0.27 & 0.32 & & 0.19 & -0.29 & 0.40 & 1 & & \\
\hline Y/Ha(tons) & 0.01 & 0.14 & 0.15 & 0.02 & 0.27 & 0.32 & & 0.19 & -0.29 & 0.40 & 0.99 & & 1 \\
\hline
\end{tabular}

*significant @ $\mathrm{P} \leq 0.05, * *$ significant $@ \mathrm{P} \leq 0.01$ 